\title{
Independent MPs, Political Party Legislation and Electoral Politics in Solomon Islands
}

https://doi.org/10.33318/jpacs.2020.40(2)-2

Lincy Pendeverana ${ }^{1}$ and Gordon Leua Nanau ${ }^{2}$

\begin{abstract}
Independent MPs have always determined formation of government in Solomon Islands. In an effort to limit the critical influence of independent MPs in forming governments, which has been a problem after almost all elections since 1974, the National Parliament of Solomon Islands debated and passed the Political Parties Integrity Act (PPIA) in 2014. The PPIA promises to limit the influence of independent MPs and prescribes how political parties are to be administered. It is also intended to establish fairer gender representation in Parliament. We noted with interest that most MPs who debated and passed the PPIA went on and contested as independent candidates. In this paper, we look at the 2014 and 2019 election results to assess the impacts, effectiveness, and weaknesses of the PPIA. We also explain why it may have failed, and highlight factors that determine voter behaviour, election outcomes, and government formation in the country. Lessons learnt from the loopholes and weaknesses of the PPIA and electoral politics more generally are then used to suggest ways forward for political party development, inclusiveness, integrity, and stability in Solomon Islands.
\end{abstract}

Keywords: Gender Equality; Independent MPs; Integrity; Political Parties; PPIA

\footnotetext{
${ }^{1}$ Faculty of Education and Humanities, Solomon Islands National University, email: lincy.pende@sinu.edu.sb

${ }^{2}$ School of Government, Development and International Affairs, The University of the South Pacific, email: gordon.nanau@usp.ac.fj
} 


\section{Introduction}

The Political Parties Integrity Act 2014 (PPIA) was passed by the Solomon Islands National Parliament in an attempt to encourage political stability. It has provisions to recognise female candidates and encourage them to contest elections, and describes how political parties are to be registered and administered. This paper relates the intentions of the PPIA, along with its effects and challenges, by specifically looking at the election results of 2014 and 2019. With the help of figures, we illustrate the composition and distribution of candidates by political party and by province following the passage and implementation of the PPIA. The election results for 2014 and 2019, and the composition of coalitions that were subsequently formed are also highlighted. We use the data to highlight the weaknesses of the PPIA and explain factors that influence voter behaviour and determine election outcomes in the country. From lessons learnt, we propose certain approaches that could be pursued to strengthen political parties, encourage gender inclusion, and boost political stability in parliament.

\section{Characteristics of Electoral Politics and Government Formation in Solomon Islands}

Before we look at the PPIA and its provisions, it is important to provide the context and features of political parties, electoral politics, and government formation in the country. Political parties proliferate in Solomon Islands but most have short life spans, formed only in the lead up to elections. Some political parties that may be regarded currently active include the Solomon Islands United Party (SIUP), founded in the 1960 by Peter Kenilorea (Snr); the People's Alliance Party (PAP), founded in 1979 by Solomon Mamaloni and David Kausimae; the Solomon Islands Liberal Party (SILP), founded in 1988 by Bartholomew Ulufa'alu; the National Party (NP), founded in 1997 by Francis Billy Hilly; the Association of Independent Members of Parliament $^{1}$ (AIMP), founded by Tommy Chan in 2001; the Solomon Islands Democratic Party (SIDP), founded by Mathew Wale in 2006; the Solomon Islands Party for Rural Advancement (SIPRA), founded in 2006 by Gordon Lilo and Dudley Tausinga; and the Ownership, Unity and Responsibility Party (OUR), founded by Manasseh Sogavare in 2019. Besides these active political parties, there are also those considered inactive but still in existence, such as the Autonomous Solomons

\footnotetext{
${ }^{1}$ The Leader of Independent MPs is a constitutional post provided for under Chapter VI, Part 2, Section 66 of the Solomon Islands Independence Order, 1978. However, a formal association of independent MPs was formed in 2001 as an in-house group of MPs with no political party affiliation.
} 
Party (ASP), founded by Dennis Lulei and Jackson Sunaone; the Direct Development Party (DDP), founded by Dick Ha'amori and Alfred Sasako; the New Nations Solomon Islands Party (NNSIP), founded by Belani Tekulu; the Peoples Federation Party (PFP), founded by Rudolf Dorah and Clement Forau; the Peoples Power Action Party (PPAP), founded by Wales Feratelia; the Rural Congress Peoples Party (RCPP), founded by Milton Talasasa; the Reform Democratic Party of Solomon Islands (RDP), founded by Danny Phillips; and the Twelve Pillars to Peace and Prosperity Party (TPPPP), founded by Delmah Nori (see Alasia, 1997; Nanau, 2010; NPSI, 2019).

Most post-colonial political parties in Solomon Islands have similar intensions to improve citizen's livelihoods, but only a handful of them strive to effectively regulate how they function to deliver services. The failure of parties to regulate themselves is demonstrated by frequent floor crossing (known locally as "grass hopping") by MPs. Here, MPs freely move between political parties, often distorting the numerical balance of power in government and leading to increased votes of no confidence that characterise Solomon Islands post-colonial history. This "ever-changing series of political alignment" is what Steeves (2011, p. 345) calls "unbounded politics". As Baker $(2019$, p. 2) says, "the political party system remains weak and so alliances remain highly fluid and still largely personality rather than ideology-based". Others also noted the affiliation of MPs being more towards their communities than anything national (Corbett \& Wood, 2013; Nanau, 2010). Under this logic, it may be concluded that governments are largely personality-based and have little to do with party policies and manifestos, a recipe for political instability in parliament.

The outcomes of elections relate mostly to personal and kin connections and have little to do with party manifestos. Such an understanding is confirmed by the results of a survey carried out by RAMSI in 2011 on what is important to individual voters (see Table 1). These reasons remain the same for all elections since independence, including both 2014 and 2019 elections. 
Table 1. Voters' Reasons for Voting their Preferred Candidates.

\begin{tabular}{llll}
\hline Reasons & Male \% & Female \% & All \% \\
\hline A good person. I like/trust him/her & 38.3 & 30 & 34.1 \\
He/she made good promises & 17 & 21.8 & 19.4 \\
He/she has done good work in my community & 17 & 18.8 & 17.9 \\
Candidate is a good leader/good MP & 23.8 & 11.3 & 17.5 \\
I think he/she will help people & 15.5 & 18.3 & 16.9 \\
He/she is well educated & 19.9 & 12.9 & 16.4 \\
He/she is from my family/tribe & 9.9 & 12.5 & 11.2 \\
Church affiliation & 9.1 & 5.0 & 7.0 \\
He/she has helped me/my family & 5.8 & 7.1 & 6.4 \\
I was told to vote for him/her & 3.9 & 5.9 & 4.9 \\
He/she is from my community/I know them well & 4.6 & 4.7 & 4.7 \\
He/she gave me money or gifts & 3.0 & 5.9 & 4.5 \\
Has money/good business person/owns a business & 3.1 & 1.2 & 2.2 \\
I like that political party/policies & 2.2 & 0.6 & 1.4 \\
Good vision for the country & 1.9 & 0.7 & 1.3 \\
I thought he/she would win & 1.2 & 0.8 & 1.0 \\
No details/other/wrong answer & 0.9 & 0.3 & 0.6 \\
Don't know & 0.9 & 1.9 & 1.4 \\
\hline Number of respondents & $\mathbf{2 1 2 8}$ & $\mathbf{2 1 5 7}$ & $\mathbf{4 2 8 4}$ \\
\hline
\end{tabular}

Source: ANU Enterprise, 2012

As demonstrated in Table 1 above, the important considerations that usually determine the success of candidates in Solomon Islands elections include the following: (i) the popularity of and trust voters have in candidates; (ii) promises and actual tangible outputs previously delivered by the candidate to the community; (iii) a good sitting MP; (iv) previous assistance to a voter's family; (v) a member of the same Christian denomination; (vi) education level attained; and (vii) the size of ones extended family and family affiliations Political party policies and a vision for the country are very low considerations by voters, scoring only 1.4 per cent and 1.3 per cent respectively. Election outcomes and voter behaviour in Solomon Islands are very much influenced by the personal connections of individual candidates with voters, or what is commonly known as the wantok system in Melanesia (Nanau, 2018). Apart from the personal connections of candidates, the influence of brokers (or campaign managers) and their own support bases often makes considerable difference between the winning candidates and others (Hiriasia, 2016, pp. 3-5). This is not peculiar to Solomon Islands, but is prevalent across Melanesia and other Pacific island countries (see Haley \& Zubrinich, 2018; Wyeth, 2017; Cox et al., 2007; Rich et al., 2007). The communal nature and close interpersonal relationships 
that people have with their kin and those who speak the same language or are from the same part of the island have implications in terms of goodwill and reciprocity. ${ }^{2}$ As such, individuals and families would discuss and support candidates they closely associate with or who may have supported them in the immediate or distant past. It is common for families to split up and support two or more competing candidates depending on their individual, marriage, and even denominational connections.

The chronic under-representation of women in Parliament is also a feature of Solomon Islands electoral politics. Again, this is not peculiar to Solomon Islands as it is also the case in most PICs. For instance, there are currently no female MPs in Vanuatu, PNG, or the Federated States of Micronesia (FSM); 1 in Tuvalu; 2 each in Nauru, and Marshall Islands; 3 each in Solomon Islands, and Tonga; 4 each in Tokelau, Palau, and Kiribati; 5 each in Niue, and Samoa; 6 in the Cook Islands; and 10 in Fiji (PWP, 2020). In Solomon Islands, three female MPs in the 50-seat parliament reflect the patriarchal nature of its parliament, where important decisions affecting men, women, youths and children are made. In 2008, the government requested the Constituencies Boundaries Commission to look at the possibility of including ten reserved seats for women representing nine provinces and the Honiara Municipality, but this did not eventuate (Solomon Times, 20 March 2019). This has been criticised from various fronts and to date remains "unfinished" business. A UNDP report pointed out that "in the Solomon Islands, grassroots activism has not been sufficient to persuade (mostly male) legislators" (UNDP 2016, p. 2). One outgoing High Court Judge, Stephen Pallarus, during his farewell speech, also challenged leaders to recognise the role of women in society and suggested that "there should be one united organisation that could harness the energy, the intelligence, the anger and outrage of how women are treated in their own country" (SIBC, 15 November 2014). The Commonwealth Observer Group recommended in their 2019 report that the country adopt Temporary Special Measures (TSMs) to increase female representation in parliament. Two options suggested include the allocation of a quota of seats for women, and a relook at financial incentives for political parties fielding women candidates (The Commonwealth, 2019, p. 15).

In recent years, the use of discretionary funds was blamed for skewed election outcomes in favour of sitting MPs and the nature of government coalitions formed. For instance, two issues cited during the 2019 election were cross-border ${ }^{3}$

\footnotetext{
${ }^{2}$ For a detailed analysis on kin-based voting in Solomon Islands, see Tony Hiriasia's (2016) study of East AreAre Constituency politics and voter behaviour.

${ }^{3}$ Cross-border registration and voting is where voters change their registration to vote in a different
} 
registration and voting, and the use of Rural Constituency Development Fund (RCDF) to the advantage of sitting MPs (Wiltshire et. al., 2019). It is nevertheless important to re-emphasize the critical point raised earlier about constituency level voting that gifting is "embedded within kin-based social organisation and kin networking and that, on its own, gifting does not always bring about political loyalty, as often assumed" (Hiriasia, 2016, p. 3). What is being witnessed in Solomon Islands is a continuous contention between structure and agency. Much understanding and analysis of Solomon Islands elections revolves around structural approaches to addressing political instability with minimal attention on agential factors, including individual behaviour and attitude, experiences, background, or things such as the feelings of leaders in the country. Such structure-agential arguments are discussed in detail by scholars like Dinnen (2008) and Leftwich (2010).

A former Solomon Islands Prime Minister, Rt. Hon. Ezekiel Alebua, observed that the main source of corruption in the 2019 election was the 2018 Electoral Act, describing it as either "ill conceived" or "intentionally drawn up" to allow sitting MPs to retain their seats (Asia Pacific Report, 15 April 2019). Money politics, either through business support from, say, logging companies or through MP contingency funds (although very difficult to prove), have always been regarded as influential in determining election outcomes and government formation in Solomon Islands and other Melanesian countries (Haley \& Subrinich, 2018: Kabutaulaka, 2005). With the above context set, we will now turn to discuss legislative changes instituted in 2014 aimed at encouraging stability and political party discipline. Perhaps the most significant attempt undertaken to encourage political stability in Solomon Islands' parliament was the passing of the Political Parties Integrity Act, 2014 (PPIA).

\section{The Political Parties Integrity Act 2014}

The PPIA aims to encourage MPs to become members of registered political parties before and after elections and not remain as independents, a tendency assumed to encourage parliamentary instability because of limited political party affiliations. This Act was an attempt to encourage political parties to take root, become massbased, and, possibly, increase member loyalty. The PPIA prescribes criteria for political party registration, including how MPs are to be disciplined if they switch party allegiances, and how to strengthen the internal organisation of political parties. It also established a Political Party Commission to oversee the enactment of the Act

constituency where they do not reside with the hope of getting personal benefits from candidates. It was reported that in 2019, there were 54,000 instances of voters wanting to change their registration to a different constituency (see Wiltshire, et al, 2019). 
and the Office of the Registrar of Political Parties responsible for administering the registration, amalgamation, and deregistration of political parties (NPSI, 2014).

Certain provisions of the PPIA ought to be highlighted. First is the requirement that a candidate must be a registered voter and a member of a political party. This is an interesting provision because in practice an intending candidate can still contest as an independent candidate and only join a party after the election when s/he is declared the winner and/or before the formation of government. There is also a provision that attempts to encourage gender representation in elections. The provision states that at least 10 per cent of candidates who apply to contest under a party must be women. This is undermined by making the provision contingent on whether there are enough women applying under the party and subsequently endorsed as party candidates. To encourage female candidates, there is also a provision for a TSM grant that political parties that retain women MPs can claim after election results are declared.

The PPIA, in its attempt to dissuade independent MPs, prescribe that an independent candidate must renounce his or her independent status and join a political party prior to or after the Oath of Allegiance is taken upon successful election. Once an MP renounces his/her independent status, s/he is deemed to be endorsed by that political party that s/he declares allegiance to. More importantly, no political party may enter into a coalition with any independent or group of independent MPs after elections. This is a controversial provision that may have also contributed to the demise of the PPIA. Nevertheless, the requirements for party registration appeared to reduce the number of political parties and independent groups that contested the 2014 election. Prior to the enactment of the PPIA, in the 2010 election, a total of twenty political parties contested, while in 2014 and 2019, only twelve and fourteen, respectively, contested the elections. Table 2 below provides the names of the political parties that contested the 2014 and 2019 elections. 
Table 2. Registered and Non-registered Parties that Contested the 2014 \& 2019 Elections.

\begin{tabular}{|c|c|c|}
\hline Election Year & 2014 & 2019 \\
\hline $\begin{array}{l}\text { Registered } \\
\text { political parties }\end{array}$ & $\begin{array}{l}\text { 1. People's Alliance Party } \\
\text { 2. Democratic Alliance party } \\
\text { 3. People's Progressive Party } \\
\text { 4. National Transformation } \\
\text { Party } \\
\text { 5. Kadere } \\
\text { 6. Solomon Islands People } \\
\text { First } \\
\text { 7. SIPRA } \\
\text { 8. United Democratic Party } \\
\text { 9. New Nation Party } \\
\text { 10. Pan-Melanesian Congress } \\
\text { Party } \\
\text { 11. Direct Development Party } \\
\text { 12. Youth Owned Rural and } \\
\text { Urban Party }\end{array}$ & $\begin{array}{l}\text { 1. People's Alliance Party } \\
\text { 2. Democratic Alliance Party } \\
\text { 3. Peoples Progressive Party } \\
\text { 4. National Transformation } \\
\text { Party } \\
\text { 5. Kadere } \\
\text { 6. Solomon Islands People } \\
\text { First } \\
\text { 7. SIPRA } \\
\text { 8. United Democratic Party } \\
\text { 9. New Nation Party } \\
\text { 10. Pan-Melanesian Congress } \\
\text { Party } \\
\text { 11. Green Party } \\
\text { 12. Solomon Islands United } \\
\text { Party } \\
\text { 13. Democratic Party } \\
\text { 14. Independents }\end{array}$ \\
\hline $\begin{array}{l}\text { Non-registered } \\
\text { political parties }\end{array}$ & $\begin{array}{l}\text { 1. OUR Party } \\
\text { 2. SI Democratic Party } \\
\text { 3. Liberal Party } \\
\text { 4. Labour Party } \\
\text { 5. Rural Urban Party } \\
\text { 6. United Party } \\
\text { 7. National Party }\end{array}$ & $\begin{array}{l}\text { 1. OUR Party (registration } \\
\text { completed after election). }\end{array}$ \\
\hline
\end{tabular}

Source: SIBC, 2014 \& 2019; SIEC, 2014 \& 2019; ST, 2014 \& 2019; NPSI, 2019

We will now present the data in the form of tables of results from the 2014 and 2019 elections and discuss key findings. It should be stated at the outset that the overall findings in the tables and discussions below is that, despite the PPIA, the characteristics discussed in the first section of the paper persist, especially in relation to the prominent role played by independent MPs, the continuing weakness of political parties, and the under-representation of women. Political instability and the unpredictable behaviour of independent MPs in government formation continued after the enactment of the PPIA. Indeed, independent MPs determined the final 
composition of government coalitions following both the 2014 and 2019 elections. Notably, most MPs that debated and passed the PPIA went on and contested both the 2014 and 2019 elections as independent candidates and not under political parties. They appear to have had little regard for the PPIA that they themselves passed to encourage political stability in parliament. On the contrary, loopholes and weaknesses inherent in the PPIA were exploited by individual MPs for political rewards. Some of these loopholes are discussed below. It is also important to point out that party affiliated MPs behave very similarly to independent MPs. They too frequently change sides.

On gender equality, the PPIA provisions failed to encourage political parties to fulfil the 10 per cent provision even with the TSM inducement grant. In the 2014 election, only one female MP was elected to parliament, Hon. Freda Tuki Soriocomua, representing Temotu Vatud constituency. She contested on a People's Alliance Party (PAP) ticket but when she got to parliament, she decided to switch allegiance to another political party. The TSM grant was never given to any political party because of that change in party loyalty. Later in the term of that particular house, an election petition unseated the then MP for Gizo/Kolombagara, Jimmy Tanangada, and a byelection was subsequently held. His wife won the by-election and became the new MP for Gizo Kolombangara. Hon. Tuki and Lanelle Tanangada became the only two female MPs in that $10^{\text {th }}$ Parliament. Unfortunately, Hon. Tuki lost her seat through an election petition and so only Hon. Lanelle Tanaganda completed the term of that Parliament. In 2019, both female MPs were re-elected and were each given ministerial portfolios. Hon. Tuki became the Minister for Women, Youth, Children and Family Affairs (MWYCFA) and Hon. Tanangada was appointed Minister for Police, National Security and Correctional Services (MPNSCS) only to resign following the government's decision to switch diplomatic relationship from Taiwan to China. She was reappointed as the Minister for Education and Human Resources Development (MEHRD) during a cabinet reshuffle in April 2020 (Solomon Times, 29 April 2020). In December 2019, a third female MP was elected into Parliament following a by-election in the East Makira constituency left vacant by the passing away of her husband and MP (RNZ, 2019b). Solomon Islands now have three female MPs in its $11^{\text {th }}$ Parliament.

\section{Composition and Provincial Distribution of Candidates, 2014 and 2019 Elections}

The number of registered political parties and candidates that contested the 2019 general election increased slightly from those that contested in 2014. Nevertheless, 
the results of both elections showed that a majority of those who won were independent candidates compared to those who contested under registered political parties. Indeed, this has been the case since 1974, even before independence, when the first coalition government was formed between some independents and the People's Progressive Party (PPP) (Kabutaulaka, 2008, p. 106). Subsequent elections also indicated higher success rates for independent candidates than those who contested under registered political parties. For example, in the 2001 election, about 40 per cent of successful candidates were independent MPs; 42 per cent in 2006; 42 per cent in 2010; 64 per cent in 2014; and 42 per cent in 2019 (Nanau, 2010; SIEC, 2019).

The provincial distribution of political parties in both 2014 and 2019 elections render some insights into political culture and behaviour in the country. The 2014 election statistics show that 55.4 per cent of the 444 candidates who contested were independent candidates (Table 3) and 64 per cent of the seats on that election were secured by independent MPs. The relatively large political parties that contested in 2014 were the United Democratic Party (7.9 per cent), People's Alliance Party (7.4 per cent), People First Party (5.4 per cent), and National Transformational Party (5.2 per cent). The success rates for registered political parties in both 2014 and 2019 elections were mixed. Tables 3 and 4 show the distribution of candidates as per province and political party/grouping.

The domination of independent candidates in 2014 and 2019 raises many questions, as the group is not a formally registered political party under the PPIA. Independent MPs are required to join a political party after elections for purposes of forming a government, as only registered political parties are entitled to form government under the PPIA. This poses issues ranging from concerns about political party allegiance and commitment, to the constitutionally recognised position of the Leader of the Independent MPs in Parliament. As mentioned above, there continues to be a constitutional provision recognising a "Leader of the Independent group of MPs" and an associated office. 
Table 3. Candidates as per Province and Party in 2014.

\begin{tabular}{|c|c|c|c|c|c|c|c|c|c|c|c|c|c|}
\hline Party & IND & DAP & PAP & PFP & PPP & UDP & SIPRA & $\mathbf{K P}$ & DDP & YRU & NTP & NNP & PMC \\
\hline Choi & 21 & 2 & 1 & 2 & & & & & & & 2 & & 1 \\
\hline West & 25 & & 6 & 2 & & 7 & 4 & 2 & & 1 & 4 & & 1 \\
\hline Isa & 10 & 1 & 1 & 1 & & 2 & & 1 & & 1 & & & \\
\hline Mala & 79 & 7 & 7 & 8 & 2 & 7 & 4 & 10 & 1 & 4 & 7 & 2 & 6 \\
\hline Centrl & 15 & & 2 & 1 & & 2 & & 2 & & 1 & & & \\
\hline $\mathrm{R} \& \mathrm{~B}$ & 2 & 1 & & & & 1 & & & & & & 1 & \\
\hline Guale & 35 & 1 & 6 & 6 & & 8 & 1 & 2 & 1 & & 3 & 2 & 5 \\
\hline HIR & 17 & & 3 & 3 & & 3 & 1 & & & 2 & 3 & 1 & 2 \\
\hline MUP & 20 & 1 & 4 & 2 & & 3 & & 2 & 1 & & 1 & & \\
\hline Temo & 22 & & 3 & 2 & 1 & 2 & 1 & 1 & & 1 & 3 & & 2 \\
\hline Total & 246 & 13 & 33 & 24 & 3 & 35 & 11 & 20 & 3 & 10 & 23 & 6 & 17 \\
\hline
\end{tabular}

Source: Wood, 2019; SIEC, 2019

Table 4. Candidates as per Province and Party in 2019.

\begin{tabular}{|c|c|c|c|c|c|c|c|c|c|c|c|c|c|c|}
\hline Party & IND & SIUP & DAP & SIDP & PAP & PFP & PPP & UDP & SIPRA & $\mathbf{K P}$ & GP & PMC & NTP & NNP \\
\hline Choi & 13 & 2 & 2 & 2 & 2 & 1 & 1 & & & & & & & \\
\hline West & 17 & 3 & 2 & 3 & 2 & 3 & & 3 & 1 & 1 & & & & \\
\hline Isa & 7 & & 3 & & 1 & & & 1 & & 1 & 2 & & & \\
\hline Mala & 43 & 12 & 6 & 6 & 7 & 5 & 1 & 5 & & 4 & & & & 1 \\
\hline Centrl & 12 & 1 & 1 & & 1 & 1 & & 1 & 1 & 2 & & & 1 & \\
\hline $\mathrm{R} \& \mathrm{~B}$ & 4 & & 1 & & 1 & & & & & & & & & \\
\hline Guale & 20 & 4 & 2 & 6 & 1 & 1 & & 2 & 2 & 1 & & 2 & 1 & \\
\hline HIR & 14 & 3 & 1 & 1 & 2 & 3 & & 1 & 1 & & & 1 & 3 & 1 \\
\hline MUP & 17 & 2 & 4 & 2 & 2 & 2 & & 3 & 3 & 2 & & & & \\
\hline Temo & 15 & 2 & 2 & 1 & 3 & 1 & & 2 & 2 & 2 & 1 & & 1 & \\
\hline Total & 162 & 29 & 24 & 21 & 22 & 17 & 2 & 18 & 10 & 13 & 3 & 3 & 6 & 2 \\
\hline
\end{tabular}

Source: Wood, 2019; SIEC, 2019

\section{Government formation: 2014 and 2019 Coalitions}

Given the affiliation of candidates that contested the 2014 and 2019 elections, it is important to determine the success rates of these candidates under their respective groups and parties. Tables 5 and 6 below show the results of 2014 and 2019 elections for candidates that contested under registered political parties and those that contested as independents. It is obvious from the results that independent candidates were more successful in securing seats in both elections. 
Table 5. 2014 Election Results.

\begin{tabular}{lll}
\hline Political Party & Seats secured & Percentage (\%) \\
\hline 1. Democratic Alliance Party & 7 & $14 \%$ \\
2. United Democratic Party & 5 & $10 \%$ \\
3, People's Alliance Party & 3 & $6 \%$ \\
4. Kadere Party of Solomon Islands & 1 & $2 \%$ \\
5. Solomon Islands People First & 1 & $2 \%$ \\
6. SI Party for Rural Advancement & 1 & $2 \%$ \\
7. Independents & 32 & $64 \%$ \\
\hline Total & $\mathbf{5 0}$ & $\mathbf{1 0 0 \%}$ \\
\hline
\end{tabular}

Source: IPU, 19 November 2014

Table 6. 2019 Election Results.

\begin{tabular}{lll}
\hline Political Party & Seats secured & Percentage (\%) \\
\hline 1. Kadere Party of SI & 8 & $16 \%$ \\
2. Solomon Islands Democratic Party & 8 & $16 \%$ \\
3. United Democratic Party & 4 & $8 \%$ \\
4. Democratic Alliance Party & 3 & $6 \%$ \\
5. People's Alliance Party & 2 & $4 \%$ \\
6. SI United Party & 2 & $4 \%$ \\
7. SI Party for Rural Advancement & 1 & $2 \%$ \\
8. Solomon Islands People First & 1 & $2 \%$ \\
9. Independents & 21 & $42 \%$ \\
\hline Total & $\mathbf{5 0}$ & $\mathbf{1 0 0 \%}$ \\
\hline
\end{tabular}

Source: SIEC, 2019

In the 2014 national general election, twelve registered and seven unregistered political parties contested (see Table 2). The majority of candidates that won seats in both 2014 and 2019 elections were independent candidates. Given the predominance of independent MPs compared to MPs affiliated to political parties in the 2019 election, the government led by Prime Minister Sogavare again formed a coalition called the Democratic Coalition for Change Government (DCCG). The DCCG comprised six political parties (Solomon Islands Democratic Party, United Democratic Party, United Party, People's Alliance Party, Peoples First, and Party for 
Rural Advancement) and a seventh political party, OUR Party, which only completed its registration after the 2019 general election, bringing together all the independent MPs formally for the first time. Strictly speaking, most of them contested as independents but they did so under the unregistered party called OUR Party in both 2014 and 2019. Unfortunately, the delayed registration of OUR Party and its pivotal role in forming a coalition after the 2019 election gave rise to a court challenge questioning the legitimacy of the registration of OUR party and the eligibility of Hon. Manasseh Sogavare's nomination as the candidate for the prime minister's position. It was ruled legitimate by the Solomon Islands High Court.

Statistics on both the 2014 and 2019 elections show that a majority of incumbent MPs retained their seats. The public saw these as indicators of vote buying, where sitting MPs use funds from the RCDF and other sources to support their campaign effort. This is supported by the increased number of petition cases received by the High Court in 2019 totalling twenty-eight cases, more than half of all the parliamentary seats $(R N Z, 2019 \mathrm{a})$. There were only fifteen petition cases against winning candidates in 2014 (SIBC, 20 December 2018). This may be attributed to the differences in levels of public awareness carried out by the Electoral Commission Office in 2014 and 2019, and the improvement of judicial and policing services inter alia. Wood (2014, p. 1) explains that, although vote buying appears to be increasing, the sensitivity around this issue made it hard to quantify. Table 7 provides some comparative statistics on the 2014 and 2019 elections.

Table 7. Summary of Important Comparative Statistics on the 2014 and 2019 Elections.

\begin{tabular}{|l|l|l|}
\hline Election Year & $\mathbf{2 0 1 4}$ & $\mathbf{2 0 1 9}$ \\
\hline Number of seats in parliament & 50 & 50 \\
Total number of candidates contested & 443 & 333 \\
Number of male candidates & $417(94.1 \%)$ & $307(92.2 \%)$ \\
Number of female candidates & $26(5.9 \%)$ & $26(7.8 \%)$ \\
Number of registered parties contested & 12 & 14 \\
Number of election petitions & 15 & 28 \\
Number of parties winning seats & 6 & 8 \\
Number of parties in government & 2 & 7 \\
& & (including OUR Party) \\
\hline
\end{tabular}

Source: The Commonwealth Observer Group, 2014; ERT \& SPC, 2016; SIBC, 2018; SIEC, 2019 


\section{Why has the PPIA Failed to Achieve its Intended Objectives?}

There are a few loopholes or weaknesses of the PPIA and the processes that led to its adoption. They include, but are not limited to, the government's piecemeal approach to addressing political instability, very weak provisions on gender equality and representation, limited impact on voter behaviour, and the fact that independent MPs have constitutional rights to form government. To start off, let us consider this point regarding independent MPs in parliament. The initial intension of the PPIA was to minimize or put a stop to "grass-hopper" politics, and part of the approach was to limit the influence of independent MPs by obligating all MPs to declare their allegiance to a registered political party before or after national elections. As highlighted throughout this paper, the role of independent MPs has been pivotal in the making and unmaking of governments in Solomon Islands. Independent MPs have been publicly criticised for their allegiance to a group that is not construed as a political party, but rather a group established to capitalise on the fluid political party system in the country.

In 2014, Hon. Mathew Wale's Solomon Islands Democratic Party (SIDP) sought legal clarification from the High Court, as they felt that some sections of the PPIA contravened the constitution, particularly their freedom of association. The High Court dismissed the case saying that the PPIA "does prescribe that an unregistered party cannot sign a coalition agreement with a registered party" (SIBC, 16 November 2014). However, it allows MPs, including independents, to enter into Memorandums of Understanding or Agreements with other political parties in parliament to form government but not under the agreement prescribed by the PPIA (SIBC, 16 November 2014). As the Commonwealth reported, "an important component of this agreement is that it must include provisions prescribing who the coalition may nominate as its candidate at the election of a new Prime Minister" (2014, p. 15). Mr. Calvin Ziru, former Registrar of Political Parties further explained that "the act does not contravene the right or freedom of association of any individual and or political party and that political parties must be registered under the act in order for them to contest the elections" (Solomon Times, 17 November 2014). Herein lies a loophole of the PPIA. Alliances and associations are protected by the national constitution. However, an unregistered party cannot sign a coalition agreement with a registered political party under the PPIA, but they can form a "coalition with other unregistered parties or other independent MPs under a simple MOU or an agreement that is not the same as agreement prescribed by the Act" (SSN, 16 November 2014). The 2014 ruling of the High Court also implied that independent MPs must join a political party in order to be able to participate in the governing of the country. Because of 
this, the support of independent MPs can either encourage stability or instability during the process of forming coalitions. This is where the weakness and failure of the PPIA lie.

A classic example was during the 2019 lobbying to form government. At that time, various political parties camped in different Honiara hotels. Two of the largest political parties, the Solomon Islands Democratic Party and the Kadere Party of Solomon Islands, only had 8 MPs each and therefore had to lobby for the support of the 21 independent MPs to form government. This was further complicated when OUR Party only completed its registration process after the election results were officially declared. Following its official registration under the PPIA, most independent MPs, including Hon Manasseh Sogavare, formally declared their allegiance to OUR Party. The party leader Hon. Manasseh Sogavare was able to form the Democratic Coalition for Change (DCC) government with the subsequent support of most independent MPs. The opposition led by Hon. Matthew Wale questioned the validity of OUR party's registration, and wanted the Governor General to delay the election of a new Prime Minister until a court decision was made on the case they filed. The Governor General decided instead to go ahead with the election of the Prime Minister and Hon. Manasseh Sogavare was duly elected while the opposition group walked out of Parliament without casting their votes. The High Court later struck out Hon. Wale's case, but that was after sporadic riots and looting in East Honiara by disgruntled and ill-informed citizens (RNZ, 2019a). Hon. Wale rejected allegations that he fuelled the riots because of his group's decision to walk away from the prime minister's election and instead blamed it on Hon. Sogavare's greed for power (ABC, 3 May 2019). In any case, independent MPs, although a loose group, not formally registered under the PPIA, wield the balance of power in the formation of governments. This has been the trend since independence in 1978. The PPIA failed to address this chronic cause of instability.

Closely related is the fact that the PPIA was developed through a piecemeal rather than a holistic approach to address political instability. Since political instability is a national concern and a longstanding one, it should have been approached holistically, taking a more political settlement approach. Here political settlement refers to "a combination of power and institutions that is mutually compatible and also sustainable in terms of economic and political viability" (Khan, 2010, p. 4). The PPIA failed to do that and only focussed on parliamentary instability and the registration and administration of political parties. It did not address other aspects of instability, such as how to reduce election petitions, potential for riots, and other factors associated with frustrated voters who cannot get the change they wish to see. 
Parliament has ignored the extensive consultations, research and analysis carried out by the constitutional reform committee that had been working on what may be regarded as a political settlement through the draft federal constitution. A loophole in the PPIA is that it attempts to address instability in Parliament while ignoring the wider implication of instability in society. The PPIA addresses the need for MPs to declare their allegiance to political parties but did little about the constitutional provision of the office of Leader of Independent MPs in Parliament as highlighted earlier.

A holistic approach, taking into account the various forces that have contributed to political instability in the country, is critical, as government formation in Solomon Islands is influenced by the politics of individual interests and not so much by party ideologies and affiliations. Political ideologies that stemmed from different party manifestos only play a useful role in governance when the personal interests of candidates or MPs are reflected in them. In such a political climate, there is always a contention between individual interest and public interest. Attaining the common good for the Solomon Islands populace always appears unachievable despite large amounts of RCDF funds injected through government budgets and aid donors annually.

The situation described may in part be attributed to the short time period since independence, when Solomon Islands had to adopt the Westminster parliamentary democracy, a system refined over centuries in the West. The challenges of introducing such a system of government in a country with more than 87 local languages and dialects (Bugotu et al., 1975, p. 12) spoken by hundreds of different tribes led one early leader of the country to express the notion that Solomon Islands was as "a nation conceived but never born" (Mamaloni, 1992, p. 14). The tensions between 1998 and 2003 contradicted efforts to unite this culturally and linguistically diverse country. As such, the PPIA failed to work towards a political compromise that would have been useful to engineer political party discipline and electoral stability in the country. As Craig and Porter suggested, "post-conflict political settlements, their compromises and combinations can develop out of 'pacts' between political and economic elites that, as they become institutionalised, provide a durable kind of stability and order" (2014, p. 1). Again, a weakness in the PPIA is its inability to accommodate the diverse aspects of instability in electoral politics and inability to work towards a political settlement instead of focussing entirely on political party registration and administration.

Finally, the PPIA has very weak provisions on gender equality to wear down the 
highly patriarchal nature of Solomon Islands society. Like other PICs, Solomon Islands will require more effort to change this cultural mind-set to pave the way for a more sympathetic and gender-sensitive approach to leadership. Since this requires cultural change, which is usually very slow change, it may be strategic to use legislation to incentivise or coerce voters to make their choices in a certain way that addresses gender equality in the political party and/or electoral system. As highlighted earlier, a prominent provision in the PPIA that attempts to address equal representation of women in parliament is the $10 \%$ provision for women contesting under political parties and the inducement grant on successful female candidates that contest under political parties. This is simply a percentage mentioned but it does not obligate political parties to set aside that percentage of spaces to female candidates since it goes on to say that only if there are enough women candidates applying to contest under the party. In a sense, this provision on gender equality is meaningless and does not have weight (Commonwealth, 2019). Examples of gender equality measures that work in the Pacific can be seen in French Polynesia, New Caledonia, Fiji, and Samoa (Baker, 2016). The PPIA could have learnt from experiences in other parts of the Pacific to strengthen gender equality provisions.

\section{Future Considerations for Improvement}

A possible way forward, given the fluidity of Solomon Islands' political party system, would be to engineer ways that either induce or coerce voters, candidates, and MPs to adhere to certain political behaviour patterns that encourage stability and cooperation. There is still a need to strengthen political parties to make them more inclusive and attractive, such as requiring them to have a wider support base and offices with women and youth wings, and continuously recruiting members. If massbased political parties are not deemed feasible after careful study and experimentation, one other option is to coerce voters and political parties to adhere to certain standards of behaviour and operation through legislation (Nanau, 2015). Solomon Islands could learn from, say, Samoa, where a registered political party is only recognised if the party secures eight or more seats in an election. Moreover, in Samoa, independent MPs and those who resign from their political parties cannot be given ministerial portfolios in the entire life of that house. ${ }^{4}$ This is justified on the grounds that allowing political parties to control and discipline MPs or to cater for

\footnotetext{
${ }^{4}$ We are conscious that the Samoan electoral law in this area led to the weakening of the opposition and have been regarded as "draconian" by external assessors. Nevertheless, it eliminated unnecessary frequent floor crossing and discouraged candidates from contesting as independents, a chronic challenge in Solomon Islands.
} 
the 10 per cent provision for female candidates through inducements have so far been unsuccessful. As such, a more coercive approach engineered through the electoral system or political parties' legislation may produce better outcomes and instigate change in voter behaviour.

There is also the opportunity to stop, rethink, and develop a new electoral system that captures the nature and political culture of the Solomon Islands. In other words, there should be a search for a "political settlement" to address instability in the country. The basis for this new electoral system could be the lessons and experiences of the past four to five decades, taking on board lessons from other PICs. There are examples such as the Proportional Representation (PR) system used in Fiji, or the preferential and two-round systems of voting that require 50 per cent support from voters in a constituency before a candidate is declared a winner. An example of such a system is used in Kiribati. Of course, adopting and refining systems borrowed from other PICs would have to be contextualised to minimise potential negative impacts of such systems experienced elsewhere. It is important to stress that some provisions under the draft Federal Constitution of Solomon Islands, which defines representation and how elections are to be carried out, could be starting points (Nanau, 2017). For instance, under the draft federal constitution, there is a provision for "recall", where an MP can be recalled by constituents if their MP is unable to fulfil his/her duties or is likely to bring disrepute to the constituency (SIG, 2018, pp. 79-80). Political will and the ability to step away from the status quo to push for such reforms are essential requirements.

Gender inequality, both in terms of candidates that contested and winners of both the 2014 and 2019 elections, demonstrates there is an urgent need to address this issue in Solomon Islands national parliament. There is a gradual increase in the number of female candidates contesting elections over the years. For instance, in 2010, 25 females (4.9 per cent) contested, in 2014, 26 (5.8 per cent) contested, and, in 2019, 26 female candidates ( 7.8 per cent) contested. In the 2019 election, only 30 per cent of female candidates (8) contested as independents, while 69 per cent (18) campaigned under various registered political parties. Could this be an indication that female candidates have more faith in political parties than their male counterparts? The gender inequality gap between men and women's participation in political leadership remains an outstanding issue to be addressed. In relative terms, women's engagement in Solomon Islands politics is only six per cent ${ }^{5}$, and demands structural and behavioural changes to improve equal representation. The Solomon

${ }^{5}$ In 2020, there are only 3 female MPs in the 50-seat parliament of Solomon Islands. 
Islands Government should address this issue in the interest of stability and a fairer representation of genders in political leadership.

\section{Conclusion}

Overall, elections in Solomon Islands are relatively peaceful and well-respected by citizens. The general concern over the years is the acute level of instability in parliament caused by MPs frequently crossing the floor, toppling governments, or creating new ones. An attempt to address this under the PPIA proved ineffective in a country where personality politics determine the making and unmaking of governments. Independent MPs who command the balance of power during political lobbies in both 2014 and 2019 were testaments to the inherent weaknesses of the PPIA. Much more could be achieved through political party engineering to strengthen political party institutions and to encourage gender equality in Solomon Islands' political processes. Positive experiences from other neighbouring countries could be adapted and contextualised to develop a more effective electoral system that will also encourage political stability without restricting the rights of representatives over leadership allegiances in parliament. This fine line between a re-engineered electoral system and democratic freedom of MPs to freely decide on allegiances is the most difficult but essential puzzle to solve in Solomon Islands. Little has changed in the behaviour of voters, political parties, and how coalitions are formed since independence, despite allegations of influence and pressures from loggers on politicians since the 1980s or the 2019 diplomatic switch from Taiwan to China. Now is probably the opportune time to reflect on the lessons learnt so far, to rethink what is best for the country and to forge a new electoral system that institutionalises political parties, addresses gender inequality, and ensures political stability for governments to deliver services.

\section{References}

Alasia, S. 1997. Party Politics and Government in Solomon Islands. SSGM.

Asia Pacific Report. 2019. Solomon Island's election among 'most corrupt', says former PM. Asia Pacific Report, 15 April 2019 $<$ https://asiapacificreport.nz/2019/04/15/solomon-islands-election-amongmost-corrupt-says-former-pm/>; accessed 27 October 2019.

ABC (Australian Broadcasting Corporation). 2019. Matthew Wale rejects claim he fueled post-election riots in Honiara. ABC Radio Australia/Pacific Beat, < https://www.abc.net.au/radio-australia/programs/pacificbeat/wale-rejectsclaim-he-fuelled-post-election-riots/11075814>; accessed 28 October 2019. 
ANU Enterprise. 2012. People's Survey 2011. Regional Assistance Mission to Solomon Islands.

Ayson, R. 2007. "The 'arc of instability' and Australia's strategic policy." Australian Journal of International Affairs, 61(2), 215-231.

Baker, K. 2016. Improving Women's Electoral Chances Through an Evidence-Based Approach: Temporary Special Measures and Institutional Approaches. In Brief 2016/36, SSGM.

Baker, K. 2019. The surprising sameness of the Solomons elections. The Intepreter. Lowy Institute: Sydney, 23 April 2019; <https://www.lowyinstitute.org/theinterpreter/surprising-sameness-solomons-elections>; accessed 5 March 2020. Bugotu, F., Maeke, D., Paia, H., Ramoni, M., \& Arnold, B. 1975. Education For What? A Report on the Findings of the British Solomon Islands Protectorate Educational Policy Review Committee. Government Printer.

Corbett, J., \& Wood, T. 2013. Profiling politicians in Solomon Islands: Professionalisation of a political elite? Australian Journal of Political Science 48(3), 320-334.

Cox, M., Alatoa, H., Kenny, L., Naupa, A., Rawlings, G., Soni, N., Vatu, C., Sokomanu, G., \& Bulekone, V. 2007. The Unfinished State: Drivers of Change in Vanuatu. AusAid.

The Commonwealth. 2014. Report of the Commonwealth Observer Group: Solomon Islands General. Honiara, 19 November 2014. Commonwealth.

The Commonwealth. 2019. Solomon Islands National General Election, $3^{\text {rd }}$ April 2019: Reports of the Commonwealth Observer Group. Commonwealth.

Craig, D., \& Porter, D. 2014. Political Settlement in Solomon Islands: A Political Economic Basis for Stability after RAMSI? Political Settlement: Part 3. In Brief 2014/12. DPA.

Dinnen, S. 2008. The Solomon Islands intervention and the instabilities of the postcolonial state. Global Change, Peace \& Security, 20(3), 339-355.

Equal Rights Trust (ERT) and SPC (The Secretariat of the Pacific Community). 2016. Stand Up and Fight: Addressing Discrimination and Inequality in Solomon Islands. Equal Rights Trust.

Hayley, N., \& Zubrinich, K. 2018. 2017 Papua New Guinea General Elections: Election Observation Report. Department of Pacific Affairs, ANU.

Hiriasia, T. 2016. Kin and Gifts: Understanding the Kin-based Politics of Solomon Islands - The Case of East AreAre. SSGM, ANU.

Kabutaulaka, T. T. 2005. Rumble in the jungle: land, culture and (un)sustainable logging in Solomon Islands. In A. Hooper (Ed.), Culture and Sustainable Development in the Pacific (pp. 88-97). ANU Press. 
Kabutaulaka, T. T. 2008. Parties, Constitutional Engineering and Governance in the Solomon Islands. In R. Rich, L. Hambly, \& M. G. Morgan (Eds.), Political Parties in the Pacific Islands (pp. 103-106). ANU Press.

Khan, M. 2010. Political Settlements and the Governance of Growth-Enhancing Institutions.

<http://eprints.soas.ac.uk/9968/1/Political_Settlements_internet.pdf>; accessed 24 July 2020.

Leftwich, A. 2010. Beyond institutions: Rethinking the role of leaders, elites and coalitions in the institutional formation of developmental states and strategies. Forum for Development Studies, 37(1), 93-111.

Mamaloni, S. 1992. The Road to Independence. In R. Crocombe \& E. Tuza (Eds.), Independence, Dependence, Interdependence: The First I D Years of Solomon Islands Independence (pp. 7-18). Institute of Pacific Studies.

McDougall, D. 2004. Intervention in Solomon Islands. The Round Table, 93(374), 213-223.

Nanau, G. L. 2010. How political parties do and do not promote democratic governance in the Solomon Islands. In K. Lawson (Ed.), Political Parties and Democracy in Africa and Oceania (pp. 201-224). Prager.

Nanau, G. L. 2015. Moving beyond the 'musical chairs' of Solomon Islands politics. DevPolicy Blog, 10 November 2015 <https://devpolicy.org/movingbeyond-the-musical-chairs-of-solomon-islands-politics-20151110/>; accessed 26 July 2020.

Nanau, G. L. 2017. Sustaining Peace in Solomon Islands through a New Constitution? Part 2: The Draft Constitution and Recent Discussions. In Brief 2017/34. DPA

Nanau, G. L. 2018. Wantoks and Kastom: Solomon Islands and Melanesia. In A. Ledeneva (Ed.), The Global Encyclopaedia of Informality (pp. 244-248). UCL Press.

NPSI (National Parliament of Solomon Islands). 2014. Political Parties Intergrity Act 2014 (No. 9 of 2014). Enacted by the National Parliament of Solomon Islands, 20 June 2014.

NPSI. 2019. Listing of Members of Parliament by Political Parties. <http://www.parliament.gov.sb/index.php?q=node/147>; accessed 7 March 2020.

PWP (Pacific Women in Politics). 2020. National Women MPs. $<$ https://www.pacwip.org/women-mps/national-women-mps/>; accessed 23 July 2020.

RNZ (Radio New Zealand). 2019a. Case against Solomons PM thrown out of court. 


\section{Radio New Zealand/Pacific,}

https://www.rnz.co.nz/international/pacific-news/390598/case-againstsolomons-pm-thrown-out-of-court>; accessed 28 October 2019.

RNZ. 2019b. Third woman elected to Solomon Island parliament. Radio New Zealand/Pacific, <https://www.rnz.co.nz/international/pacificnews/405501/third-woman-elected-to-solomon-islands-parliament>; accessed 23 July 2020.

Rich, R., Hambly, L., \& Morgan, G. (Eds.) 2007. Political Parties in the Pacific Islands. ANU E Press.

SIBC (Solomon Islands Broadcasting Corporation). 2014. Women Organisations Combine to be Effective: Parallas. SIBC: Voice of the Nation, 15 November 2014, <http://www.sibconline.com.sb/women-organisationscombine-to-be-effective-pallaras/>; accessed 26 October 2019.

SIBC (Solomon Islands Broadcasting Corporation). 2019. 15 parties vying for election. SIBC:

Voice of the Nation, 4 February 2019, < http://www.sibconline.com.sb/15-partiesvying-for-election/>; accessed 6 October 2020.

SIG (Solomon Islands Government). 2018. Constitution of the Federal Republic of Solomon Islands, Final Report 2018. Constitutional Congress \& Eminent Person's Group, PMO.

SIEC (Solomon Islands Electoral Commission). 2014. Election Results. < http://www.siec.gov.sb/index.php/elections/election-results>; accessed 6 October 2020.

SIEC (Solomon Islands Electoral Commission). 2019. Election Results. $<$ http://www.siec.gov.sb/index.php/nge-elections/electionresults.html>; accessed 26 October 2019.

ST (Solomon Times). 2014. High Court Upholds Integrity Bill. Solomon Times: Solomon Islands News, 17 November 2014, < https://www.solomontimes.com/news/high-court-upholds-integritybill/8311>.

ST (Solomon Times). 2019. Uneven Playing Field for Women in Politics. Solomon Times: Solomon Islands News, 20 March 2019, < https://www.solomontimes.com/news/uneven-playing-field-forwomen-in-politics/8927>; accessed 26 October 2019.

Steeves, J. 2011. 'Unbounded politics' and the democratic model in Solomon Islands: The 2010 national elections. Commonwealth \& Comparative Politics, 49(3), 432-358.

UNDP. 2016. Temporary Special Measures to Increase Women's Political 
Participation in the Pacific: Case Studies of Implementation in the Region. UNDP Office.

Wainwright, E. 2003. "Responding to state failure-the case of Australia and Solomon islands." Australian Journal of International Affairs, 57(3), 485-498.

Wiltshire, C., Batley, J., Ridolfi, J., Rogers, A. 2019. 2019 Solomon Islands National General Elections Observation Report. ANU Department of Pacific Affairs.

Wood, T. 2014. Elections and Electoral Quality in Solomon Islands, In Brief 2014/40. ANU.

Wood, T. 2019. Solomon Islands Election Results Database 1967-2019. Accessed online at: http://solomonselections.org/; accessed on 14 November 2019. Wyeth, G. 2017. Big Men, No Women: Politics in Papua New Guinea. The Diplomat $<$ https://thediplomat.com/2017/08/big-men-no-women-politics-inpapua-new-guinea/>; accessed 23 July 2020. 